\title{
FORMULATION AND EVALUATION OF ANTI ACNE GEL CONTAINING CITRUS AURANTIFOLIA FRUIT JUICE USING CARBOPOL AS GELLING AGENT
}

\author{
SRI AGUNG FITRI KUSUMA ${ }^{*}$, MARLINE ABDASSAH², BOBBY ELLYAS VALAS ${ }^{1}$
}

1Department of Biology Pharmacy, Faculty of Pharmacy, Padjadjaran University, Sumedang, West Java, Indonesia 45363, 2Departement of Pharmaceutics, Faculty of Pharmacy, Padjadjaran University, Sumedang, West Java, Indonesia 45363

Email: s.a.f.kusuma@unpad.ac.id

Received: 18 Apr 2018, Revised and Accepted: 06 Jun 2018

\section{ABSTRACT}

Objective: The objective of this study was to design a product of anti-acne gel containing Citrus aurantifolia fruit juice as an effective antibacterial to treat acne caused by Propionibacterium acne and Staphylococcus epidermidis using carbopol as a gelling agent.

Methods: The fresh juice of $C$. aurantifolia fruit was obtained by juicer and pasteurized for $30 \mathrm{~min}$ at $65-70{ }^{\circ} \mathrm{C}$. The minimum inhibitory concentration (MIC) of the fruit juice was determined using the microdilution method. Then, carbopol in different concentration was incorporated in a gel base formula to obtain a stable gel base. The fresh juice in different formulas (F1, F2 and F3) was evaluated for $28 \mathrm{~d}$. The color, pH and viscosity of each formula were observed. In addition, the antibacterial potency of each formula was analyzed using the agar diffusion method against both tested bacteria.

Results: The citrus MIC values of both test bacteria showed different results, $20-40 \% \mathrm{v} / \mathrm{v}$ for $P$. acne and 5-10 \% v/v for S. epidermidis. The MIC values were converted into in vivo concentration and the resulted concentrations for each formula were 25,50 and $75 \% \mathrm{v} / \mathrm{v}$. For supporting the formula, the most stable base gel was achieved using carbopol $1 \%$ as the gelling agent. Among three formulas, the anti-acne gel formula containing $75 \%$ fruit juice with carbopol $1 \%$ was the best formula based on the physical and microbiological parameter.

Conclusion: Thus, it was concluded that the antiacne gel of fruit juice of $C$. aurantifolia with carbopol as a gelling agent could produce the effective and stable gel of anti-acne product.

Keywords: Citrus aurantifolia, Juice, Carbopol, Anti-acne, Gel

(C) 2018 The Authors. Published by Innovare Academic Sciences Pvt Ltd. This is an open access article under the CC BY license (http://creativecommons.org/licenses/by/4.0/) DOI: http://dx.doi.org/10.22159/ijap.2018v10i4.26788

\section{INTRODUCTION}

Acne is a skin disease with the highest prevalence among other skin disorders. Almost everyone has experienced acne prone skin, especially in an adolescent. Although it is considered not as a dangerous disease, but in fact, almost all acne sufferers feel disturbed appearance that often leads to lower levels of confidence and interfere with the daily activities. No wonder, if most patients who come to the skin care clinic are those who seek a solution to overcome the acne. According to one of a dermatologist, about 70 percent of patients who come, have acne problems.

The infection of acne vulgaris exhibits wide distribution and its prevalence increase over time [1]. Acne is the most dominant skin disease reported based on large studies in the USA, France, and the UK [2-4]. In Indonesia, about $95-100 \%$ of men and $83-85 \%$ of women aged 16-17 y suffer acne. The prevalence of acne in adult females is about $12 \%$ and in adult males $3 \%$. Another study found that acne is a skin problem of adolescence with a higher prevalence of women than men in the age range of $20 \mathrm{y}$ or older [5].

Acne vulgaris is characterized by various clinical conditions such as scaly red skin (seborrhea), erythematous papules and pustules, comedones, nodules, deep pustules, and sometimes piples [6]. The pathogenicity mechanism of acne was the production of sebums, follicular hyperkeratinization, bacterial colonization, and inflammation [7-10]. P. acne plays a role in the development of inflammatory acne by activating complements and can metabolize sebaceous triglycerides into fatty acids, which neutrophils were attracted [11]. In addition, S. epidermidis within sebaceous unit responsible in superficial infection [12]. When bacteria colonize into the comedons, then the inflammatory factors are released by those bacteria. This made the comedons transformed into pustules and pimples. The inflamed acne becomes rupture and forms nodulus, also probably forms scars after healing [13].

The type of acne, acne severity grading, number of lesions and anatomic location will determine the treatment. The treatment of acne can be given by topical or systemic therapy. The topical therapies include antibiotics, anti-inflammatory and comedolytic agent [14]. Benzoyl peroxide or its combination with clindamycin or erythromycin can treat acne effectively and recommended as an antibacterial agent for $P$. acne through the release of free oxygen radicals, also reported has a comedolytic agent $[15,16]$. But the limitation of benzoyl peroxide therapy is its concentration-dependent irritation, bleaching of bed linen, hair and fabric and causing irritant dermatitis $[17,18]$. For systemic therapy, oral antibiotics such as tetracyclines and its derivatives were the first choice [19]. It is indicated mainly for moderate-to-severe inflammatory acne [10]. But long-term therapy of oral antibiotic, not only can induce bacterial resistance but also associated with the incidence of upper respiratory tract infection [20]. The presence of bacterial resistance and unexpected side effects opens the opportunities for traditional medicine to replace the effectiveness of synthetic drugs in overcoming acne vulgaris.

Citrus family is a widely consumed group of fruits which contains several metabolites such as flavonoids, ascorbic acid and carotenoids [21]. Citrus aurantifolia is one of the citrus species that widespread and consumed lime species in Indonesia. Traditionally, this fruit juice has long been used as an ant acne herb and it effectively has been proven. But if the fruits must be squeezed first, then the treatment becomes not optimal and not practical. Meanwhile, to overcome the problem of acne against $P$. acne and $S$. epidermidis required anti-acne preparations that have good penetration and long contact time. Therefore, in this study, $C$. aurantifolia juice is formulated in the form of anti-acne gel preparations. Gel preparation can be used as an option for anti-acne preparations. The gel dosage form can last long in the skin and the release of good active substances. Gel formulation makes the preparation more easily removable from the skin then ointment and cream $[22,23]$. This study was conducted to develop an anti-acne gel formulation of $C$. aurantifolia fruit juice using carbopol as a gelling agent because another study reported that carbopol showed the superior drug release in gel formulation [24]. 


\section{MATERIALS AND METHODS}

\section{Materials}

The mature fresh fruits of $C$. aurantifolia were collected from Tasikmalaya, West Java, Indonesia and authenticated (No.023/ $\mathrm{HB} / 11 / 2015$ ) by Institute of plant determination in the department of biology, Faculty of mathematics and natural sciences, Padjadjaran University, Jatinangor, Indonesia. The tested bacteria used in this study were Propionibacterium acnes and Staphylococcus epidermidis, obtained from PT. Biofarma and Microbiology Laboratory, Faculty of Pharmacy Universitas Padjadjaran. The growth medium used was Mueller Hinton Agar (MHA-OXOID) and Mueller Hinton Broth (MHBOXOID). The chemicals used were amyl alcohol, $10 \%$ ammonia, $2 \mathrm{~N}$ hydrochloric acid, iron (III) chloride, ether, chloroform, anhydrous acetic acid solution in concentrated $\mathrm{H} 2 \mathrm{SO}$, 1\% gelatin, reagent Dragendorff (potassium bismuth iodide solution). Mayer reagents (potassium mercury iodide solution), 10\% vanillin solution in concentrated $\mathrm{H} 2 \mathrm{SO} 4,1 \mathrm{~N}$ sodium hydroxide, potassium permanganate powder, magnesium powder, and sterile physiological sodium chloride, demineralized water, ethanol, carbopol, propylene glycol, methylparaben/propylparaben and triethanolamine.

\section{Juice fruit preparation}

Whole fresh fruits were washed with potassium permanganate $1.5 \%$, then the fruit juice was taken and filtered using a separated funnel with filter paper, then the juice was sterilized by pasteurization at a temperature of $65-70^{\circ} \mathrm{C}$ for $30 \mathrm{~min}$.

\section{Phytochemical screening}

Phytochemical screening was done by a phytochemical screening of plants method to determine the secondary metabolite group found in the fruit juice of $C$. aurantifolia. Those metabolites include alkaloids, flavonoids, polyphenols, tannins, monoterpenoids, sesquiterpenoids, steroids, triterpenoids, quinones, and saponins [25].

\section{MIC determination}

Determination of MIC was performed using microdilution method with microtiter plates 96 wells. Each column is filled with $100 \mu \mathrm{l}$
MHB. Column 1 was used as a positive control, column 2 as a negative control, column 3 as the control of the juice, and column 4-12 as the test column. Then, as much as $100 \mu \mathrm{l}$ juices were suspended into column 4 and homogenized by pipetting. From column 4 , it was taken as much as $100 \mu \mathrm{l}$ and put into column 5 to obtain a juice concentration less than half concentration compared to the juice concentration in column 4 . Thus, until column 12 and last was removed $100 \mu \mathrm{l}$ from column 12 , so that all columns only contain $100 \mu \mathrm{l}$ test media suspension. As a positive control filled with $100 \mu \mathrm{l}$ MHB and $10 \mu \mathrm{l}$ suspensions of the test bacteria. Then into all columns, except column 2, inoculated with $100 \mu \mathrm{l}$ suspensions of the test bacteria. The microtiter plate was closed and incubated at $37^{\circ} \mathrm{C}$ for $18-24 \mathrm{~h}$. Petri dishes contain the most active test materials with the smallest concentrations showing the least growth and the last growth of test bacteria was determined as the range of MIC values. The incubation of MIC, observed by its turbidity and concentration resulting in a clear test medium, was taken as much as $10 \mu \mathrm{l}$ to be reinoculated on a solid MHA surface. The test medium was incubated at $37^{\circ} \mathrm{C}$ for $18-24 \mathrm{~h}$. The petri dish contains the most active test material with the smallest concentration that did not show the growth of test bacteria determined as the MBC value range.

\section{Formulation and evaluation of gel base}

Gel of fresh juice from C. aurantifolia was made using a varying concentration of carbopol as a gelling agent. In this gel base, distilled water was used as the solvent, methylparaben as a preservative, and propylenglycol as a humectant, the formula can be seen in table 1 . The carbopol was dissolved in demineralized water which has been heated to a temperature of $70{ }^{\circ} \mathrm{C}$ inside the mortal, then stirred slowly to form a homogeneous dispersion. Each of TEA and propylene glycol was dissolved in demineralized water separately and stirred. The TEA solution was added to carbopol solution and stirred until homogeneous. The $\mathrm{pH}$ of that mixed solution was adjusted to 7.4 and the propylene glycol solution was added and stirred until a clear consistent gel base was obtained. The gel was kept for $24 \mathrm{~h}$ until the bubbles were disappeared, then the $\mathrm{pH}$ and gel viscosity was measured.

Table 1: Preformulation of the base gel

\begin{tabular}{llll}
\hline Composition & Formula 1 & Formula 2 & Formula 3 \\
\hline Juice fruit & - & - & - \\
methyl paraben & $500 \mathrm{mg}$ & $500 \mathrm{mg}$ & $500 \mathrm{mg}$ \\
TEA & $2 \mathrm{ml}$ & $2 \mathrm{ml}$ & $2 \mathrm{ml}$ \\
Carbopol & $0.8 \mathrm{~g}$ & $1 \mathrm{~g}$ & $1.2 \mathrm{~g}$ \\
propylenglycol & $10 \mathrm{ml}$ & $10 \mathrm{ml}$ & $10 \mathrm{ml}$ \\
demineralized water & Add $100 \mathrm{ml}$ & Add $100 \mathrm{ml}$ & Add $100 \mathrm{ml}$ \\
\hline
\end{tabular}

\section{Formulation and evaluation of anti-acne gel}

To the base, lemon juice which has been added with methyl-paraben and has been diluted with ethanol was added. Stirring was stopped and the gel was stored in a sealed container. The gel was kept for 24 $\mathrm{h}$ until the bubbles were disappeared. The detail formula of fruit juice can be seen in table 2 . The observation of the physical stability of $C$. aurantifolia juice preparation comprised an examination of organoleptis, $\mathrm{pH}$, and viscosity during storage in climatic chamber, for $28 \mathrm{~d}$. Organoleptic test was performed to see the physical appearance of the preparation by observing the color, odor, and texture of the preparations that have been made [26]. The gel preparation was tested for homogeneity by applying it to a glass of preparation (transparent), thus, the presence or absence of particles/substances that have not been mixed homogeneously can be observed [27]. The preparation was prepared in a $100 \mathrm{ml}$ beaker glass, then the spindle with a certain number and a certain speed (rpm) was set and then dipped into the preparation until the apparatus showed the viscosity value of the preparation. The viscosity value (cPs) shown in the RION Viscometer tool was the viscosity of the dosage. Evaluation of viscosity, done by using spindel R5 with speed of $30 \mathrm{rpm}$. The $\mathrm{pH}$ of gel preparation was measured using a calibrated $\mathrm{pH}$ meter [27]. All formulas gel evaluation were observed on $0,7,14,21$ and $28 \mathrm{~d}$ of gel storage at room temperature.

Table 2: Composition of an anti-acne gel formula

\begin{tabular}{llll}
\hline Component & Formula I & Formula II & Formula III \\
\hline Fruit juice & $25 \mathrm{ml}$ & $50 \mathrm{ml}$ & $75 \mathrm{ml}$ \\
Carbopol & $1 \mathrm{~g}$ & $1 \mathrm{~g}$ & $1 \mathrm{~g}$ \\
TEA & $3.2 \mathrm{ml}$ & $4.2 \mathrm{ml}$ & $5.3 \mathrm{ml}$ \\
Propylenglycolm & $10 \mathrm{ml}$ & $10 \mathrm{ml}$ & $10 \mathrm{ml}$ \\
Ethyl paraben & $500 \mathrm{mg}$ & $500 \mathrm{mg}$ & $500 \mathrm{mg}$ \\
demineralized water & Ad $100 \mathrm{ml}$ & Ad $100 \mathrm{ml}$ & $\mathrm{Ad} 100 \mathrm{ml}$ \\
\hline
\end{tabular}




\section{Preparation of bacterial suspension}

McFarland solution consisted of two components, $1 \% \mathrm{BaCl}_{2}$ and $1 \% \mathrm{H}_{2} \mathrm{SO}_{4}$. A total of $0.05 \mathrm{ml}$ of $1 \% \mathrm{BaCl}_{2}$ solution was mixed with $9.95 \mathrm{ml}$ of $1 \% \mathrm{H}_{2} \mathrm{SO}_{4}$ solution and shaken homogeneously. The turbidity of the solution was measured at a wavelength of $530 \mathrm{~nm}$ by using distilled water as a blank. The absorbance value of the standard solution should be in the range of 0.08 to 0.13 . The standard McFarland 0.5 solutions are equivalent to a bacterial cell suspension with a concentration of $1.5 \times 10^{8}$ $\mathrm{CFU} / \mathrm{ml}$. The tested bacteria were scratched on the surface of slant agar, then incubated for $18-24 \mathrm{~h}$ at $37^{\circ} \mathrm{C}$. Each of $P$. acnes and $S$. epidermidis colonies were taken using Ose, then suspended into sterile physiological $\mathrm{NaCl}$. The bacterial turbidity was measured using a spectrophotometer at $\lambda 530 \mathrm{~nm}$, compared with a 0.5 Mc Farland solution [28].

\section{Anti-acne activity}

The efficacy of anti-acne gel formulas was performed using the agar diffusion method with perforation technique against $P$. acne and S. epidermidis. A total of $20 \mu \mathrm{l}$ bacterial suspension was fed into sterile petri dishes and suspended in $20 \mathrm{ml}$ of the MHA which was poured into the sterile petri dish. The test medium was homogenized and allowed to solidify. Media that has been solidified, then perforated to make holes for sample reservoir. The tested juice concentrations were $10,25,50$, and $75 \mathrm{w} / \mathrm{w}$. A total of $50 \mathrm{mg}$ of each concentration was introduced using a sterile syringe into the reservoir on the test medium. The negative and positive control was prepared, where the negative control contains the only medium, meanwhile the positive control consisted of the inoculated bacterial suspension using the streak inoculation method. All test and control media were incubated at $37^{\circ} \mathrm{C}$ for $24 \mathrm{~h}$. The inhibitory diameter formed was measured using a caliper.

\section{RESULTS AND DISCUSSION}

\section{Fruit juice result}

From $10 \mathrm{~kg}$ of $C$. aurantifolia fruits, a volume of $3.2 \mathrm{~L}$ rendemen juice was obtained. The $\mathrm{pH}$ of the juices was 5 and it is in accordance with the $\mathrm{pH}$ normal of the face is 4.5-6. The term of $\mathrm{pH}$ is used to describe the acidalkaline ratio of a substance ranging. Skin $\mathrm{pH}$ is normally acidic, ranging between 4 and 6, while the body's internal environment maintains a neutral to slightly alkaline $\mathrm{pH}(\sim 7.4)[29,30]$. Variable skin $\mathrm{pH}$ values are being reported in the literature, all in the acidic range, but with a broad range from $\mathrm{pH} 4.0$ to 7.0. In another study, based on the measurement of the biophysical parameters of barrier function, moisturization and scaling, it found that skin with $\mathrm{pH}$ values below 5.0 is in a better condition than skin with $\mathrm{pH}$ values above 5.0 [31]. The relation between skin $\mathrm{pH}$ and acne also had been reported that the majority of acne occurrences in the case group were related to high skin $\mathrm{pH}$ [32]. Because one of the natural barriers of skin is the acidic $\mathrm{pH}$ of stratum corneum. Thus, a shift in $\mathrm{pH}$ of the normal skin causes the barrier dysfunction and finally, acne vulgaris occur [33-35]. As the skin pH rises, normal flora disturbed and diminished the antimicrobial peptide produced by the normal flora. Therefore, the population of acne vulgaris causing bacteria increased and infection resulted [36-38].

\section{Phytochemical screening of fruit juice}

The following secondary metabolites were found to present in the fruit juice of $C$. aurantifolia. The metabolites were recorded in table 3 . Flavonoid is well known antibacterial agent that had been studied. Flavonoid had been reported showed antimicrobial activities against $P$. acnes, and S. epidermidis $[39,40]$. In another study, tannins and flavonoids in green tea also proven that possess an anti-acne effect, since they seem to have an antiseptic effect while tannins also have an antiinflammatory effect [41]. Until now, the popularity of herbal drug increasing because of its advantages such as patient tolerance, long-term use with fewer side-effects and relatively cheap [42].

Table 3: Phytochemical screening

\begin{tabular}{ll}
\hline Metabolites & Result \\
\hline Alkaloids & + \\
flavonoids & + \\
polyphenols & - \\
tannins & + \\
monoterpenoids & - \\
sesquiterpenoids & - \\
steroids and triterpenoids & - \\
quinones & - \\
saponins & - \\
\hline
\end{tabular}

Notes: $(+)$ presence; $(-)$ absence

\section{MIC determination result}

The MIC value of the fruit juice is needed to determine the dosage in the formula. This in vitro dose was then multiplied 2-4 times to obtain an in vivo dose or the test dose used in the formula. MIC results can be seen in table 4. Based on the data in the table, it was known that the MIC value of C. aurantifolia juice against $S$. epidermidis was lower than against $P$. acnes. This showed that the juice was more effective work as an antiacne against $S$. epidermidis. The MIC value of $S$. epidermidis was 5-10 \% $\mathrm{w} / \mathrm{v}$, whereas against $P$. acnes was $20-40 \% \mathrm{w} / \mathrm{v}$.

Table 4: MIC result

\begin{tabular}{lll}
\hline Concentration & & Bacterial Growth \\
\cline { 2 - 3 }$(\% \mathbf{w})$ & S. epidermidis & P. acnes \\
\hline 40 & - & - \\
20 & - & + \\
10 & + & + \\
5 & + & + \\
2.5 & + & + \\
Positive control & - & - \\
Negative control & & + \\
\hline
\end{tabular}

\section{Formulation and evaluation of gel base result}

Gels are a semisolid preparation that is used for skin with easier application than lotions and creams. Creams and lotions are rapidly cleared from the skin, thus, provide poor bioavailability of the drug [43]. By applying the gel on the skin, can be convenient because gel can spreadable and washable, hence we are no need to remove it from the skin. In addition, gel application possesses the capability to release 
active agents immediately, regardless of the water solubility of the active agent. By applying the juice of $C$. aurantifolia in the form of gel, can produce anti-acne products that are comfortable, effective and easy to use. Considering the use of this juice is generally only squeezed and used directly, so it is not durable and inconvenient. Hence the in vitro studies were carried out to formulate the $C$. aurantifolia juice in various concentrations using carbopol as the gelling agent. In this study, carbopol was chosen as a gelling agent because carbopol was reported to have more gelling property than another polymer [44]. The results of the gel base evaluation can be seen in table 5 .

Table 5: Evaluation of base gel preformulation

\begin{tabular}{|c|c|c|c|c|c|c|c|c|c|}
\hline \multirow[t]{3}{*}{ Day } & \multicolumn{9}{|l|}{ Formula } \\
\hline & \multicolumn{3}{|l|}{1} & \multicolumn{3}{|l|}{2} & \multicolumn{3}{|l|}{3} \\
\hline & Viscosity & pH & Color & Viscosity & pH & Color & Viscosity & pH & Color \\
\hline 1 & $121 \pm 0.50$ & $9 \pm 0.00$ & transparent & $145 \pm 0.50$ & $9 \pm 0.00$ & transparent & $163 \pm 0.50$ & $9 \pm 0.00$ & transparent \\
\hline 7 & $126 \pm 0.57$ & $9 \pm 0.00$ & transparent & $148 \pm 0.00$ & $9 \pm 0.00$ & transparent & $152 \pm 0.57$ & $9 \pm 0.00$ & transparent \\
\hline 14 & $134 \pm 0.57$ & $9 \pm 0.00$ & transparent & $148 \pm 0.50$ & $9 \pm 0.00$ & transparent & $145 \pm 0.00$ & $9 \pm 0.00$ & transparent \\
\hline 21 & $142 \pm 0.50$ & $8 \pm 0.00$ & transparent & $152 \pm 0.57$ & $9 \pm 0.00$ & transparent & $142 \pm 0.50$ & $9 \pm 0.00$ & turbid \\
\hline 28 & $140 \pm 0.00$ & $8 \pm 0.00$ & turbid & $145 \pm 0.50$ & $9 \pm 0.00$ & transparent & $150 \pm 0.50$ & $9 \pm 0.00$ & turbid \\
\hline
\end{tabular}

Carbopol also are not absorbed into the body and irritation free. Carbopol polymer proved to be a promising carrier for controlled release of active phytoconstituents in the gel formulation. Another study reported that the gel formulations prepared with Carbopol as a gelling agent were found to be superior to the gel formulations. Hence the effective concentration of formulatingcarbopol was determined for the best base gel formulation. Carbopol is a synthetic polymer made of carbomers that are cross-linked together to form a microgel structure. In nature, carbopol is anionic, therefore, need neutralization for microgel structure by adding triethanolamine [45]. Triethanolamine was added as a neutralizing agent for acidic carbopoles, since triethanolamine contains 56 to $86 \%$ carboxylic acid. Triethanolamine also acts as a stabilizer and developer of carbopol and prevents the disruption of disperse from carbopol when exposure to light causes the gel to become cloudy. Methylparaben is added as a preservative. This is because the use of water medium, which is very vulnerable to microbial growth. While the addition of propylenglikol used as humektan. Propylene glycol is reported to be the two best permeation enhancers [46, 47]. Meanwhile, triethanolamine were used in the formulation in order to adjust the $\mathrm{pH}$ of the formulation. In this study, three different base gel formulations were prepared using different concentrations of carbopol $(0.8 ; 1$ and $1.2 \% \mathrm{w} / \mathrm{v})$. Carbopol with $1 \%$ concentration yields the most stable gel base formula among other formulas. The $\mathrm{pH}$ of the base of the gel throughout the formula shows an alkaline $\mathrm{pH}$ over the same range, but until the end of storage, the formula with $1 \%$ carbopol concentration shows a clear gel base with a stable viscosity. Thus carbopol $1 \%$ will be continued as a gelling agent in the next stage of formulation.

\section{The result of anti-acne gel formulation and evaluation}

All fruit juice of $C$. aurantifolia gel preparations were evaluated for their physical characterization like $\mathrm{pH}$, viscosity, and color as shown in table 6. Based on the evaluation of the fruit juice extract preparation, the juice could lower the $\mathrm{pH}$ of the gel base to a $\mathrm{pH}$ corresponding to the normal range $\mathrm{pH}$ of the skin. In addition, the viscosity of the all fruit juice gel formula decreased with the increasing of storage time. The viscosity range of the three formulas was ranged from 135-148 $\mathrm{dPa}$. But interestingly, in formula 3, found that the viscosity was increased after a period of time storage. This may be due to the effect of the highest concentration of juice on formula 3 with the highest acidity among the other two formulas. The formula 3 with $75 \%$ juice concentration was hypothesized could neutralize the $\mathrm{pH}$ of base gel and resulted in the increasing viscosity of the gel.

Table 6: Anti-acne gel evaluation

\begin{tabular}{|c|c|c|c|c|c|c|c|c|c|}
\hline \multirow[t]{3}{*}{ Day } & \multicolumn{9}{|l|}{ Formula } \\
\hline & \multicolumn{3}{|l|}{1} & \multicolumn{3}{|l|}{2} & \multicolumn{3}{|l|}{3} \\
\hline & Viscosity & pH & Color & Viscosity & pH & Color & Viscosity & pH & Color \\
\hline 1 & $142 \pm 0.50$ & $6 \pm 0.50$ & Transparent yellow & $147 \pm 0.00$ & $6 \pm 0.00$ & Transparent yellow & $135 \pm 0.00$ & $6 \pm 0.00$ & Transparent yellow \\
\hline 7 & $138 \pm 0.50$ & $6 \pm 0.00$ & Transparent yellow & $145 \pm 0.00$ & $6 \pm 0.00$ & Transparent yellow & $143 \pm 0.00$ & $6 \pm 0.00$ & Transparent yellow \\
\hline 14 & $138 \pm 0.50$ & $6 \pm 0.00$ & Transparent yellow & $144 \pm 0.00$ & $6 \pm 0.00$ & Transparent yellow & $142 \pm 0.00$ & $6 \pm 0.00$ & Transparent yellow \\
\hline 21 & $136 \pm 0.50$ & $6 \pm 0.00$ & Transparent yellow $\mathrm{t}$ & $142 \pm 0.00$ & $6 \pm 0.00$ & Transparent yellow & $140 \pm 0.00$ & $6 \pm 0.00$ & Transparent yellow \\
\hline 28 & $135 \pm 0.50$ & $6 \pm 0.00$ & Transparent yellow & $138 \pm 0.00$ & $6 \pm 0.00$ & Transparent yellow & $141 \pm 0.00$ & $6 \pm 0.00$ & Transparent yellow \\
\hline
\end{tabular}

Based on the evaluation of the fruit juice extract preparation, the juice could lower the $\mathrm{pH}$ of the gel base to a $\mathrm{pH}$ corresponding to the normal range $\mathrm{pH}$ of the skin. In addition, the viscosity of the all fruit juice gel formula decreased with the increasing of storage time. The viscosity range of the three formulas was ranged from 135-148 dPa. But interestingly, in formula 3 , found that the viscosity was increased after a period of time storage. This may be due to the effect of the highest concentration of juice on formula 3 with the highest acidity among the other two formulas. The formula 3 with $75 \%$ juice concentration was hypothesized could neutralize the $\mathrm{pH}$ of base gel and resulted in the increasing viscosity of the gel. The $\mathrm{pH}$ of all formulations was at $\mathrm{pH} 6$, which fall in the normal $\mathrm{pH}$ range of skin. Therefore, all developed formulas might not irritate the face skin and can avoid the flora normal disturbance. The transparent gel of $C$. aurantifolia juice, which resulted from all formulas exhibited good stability behaviour regarding the viscosity, $\mathrm{pH}$ 6, and its appearance.

\section{Anti-acne activity}

The topical treatment of infectious disorders and skin inflammations such as acne is desirable and assures advantages than other administration of treatment. The topical application can eliminate the gastrointestinal irritation and avoid first pass metabolism. The skin can lower the bioavailability of the active substance so that it can reduce the antibacterial effect to the pathological site of acne. Therefore, the topical dosage form is the most appropriate form to facilitate active moiety into the pilosebaceous skin unit. The release of the active substance is also strongly influenced by some physical characters, especially the viscosity of the gel preparation and the viscosity is mainly correlated with the concentration of the gelling agent like carbopol.

Anti-acne activity of all formula gels indicated that $C$. aurantifolia in gel preparation was more effective as anti-acne against both tested bacteria, than its pure fruit juice. The details of the inhibition were performed in table 7. All formulas resulted in higher inhibitory diameter against $P$. acne than to $S$. epidermidis. This was very interesting, considering that the main pathogen of acne was caused by $P$. acne and the P. acne was sensitive to all formulas gel containing C. aurantifolia fruit juice. But the more increasing juice concentration exhibited the more diameter of inhibition zone against both of tested bacteria. Thus, the formula 3 gave the highest anti-acne activity against $P$. acne and S. epidermidis. This result can be clearly seen in fig. 1. 
Table 7: Anti-acne activity result

\begin{tabular}{lll}
\hline Concentration & Inhibitory diameter (mm) \\
\cline { 2 - 3 } & S. epidermidis & P. acnes \\
\hline Fruit juice not formulated (100\%pure) & $10.46 \pm 0.01$ & $14.32 \pm 0.02$ \\
Formula 1 & $18.21 \pm 0.05$ & $17.53 \pm 0.04$ \\
Formula 2 & $20.26 \pm 0.01$ & $23.54 \pm 0.04$ \\
Formula 3 & $24.76 \pm 0.01$ & $25.42 \pm 0.01$ \\
\hline
\end{tabular}

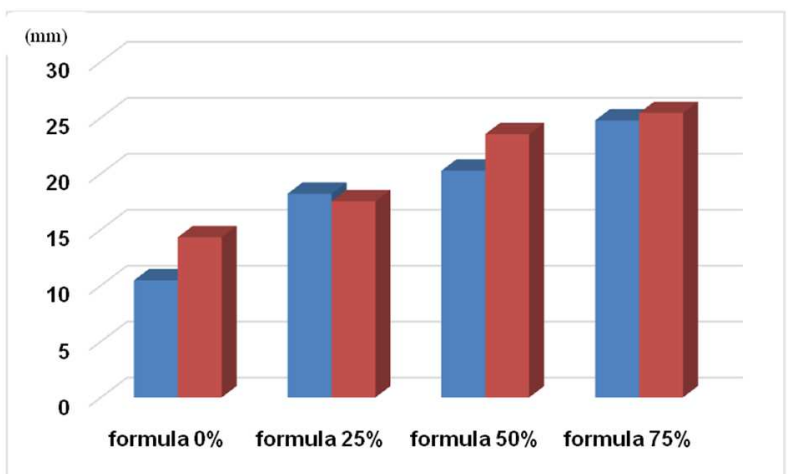

Fig. 1: Effect of juice concentration on inhibitory diameter against tested bacteria Notes: Blue (S. epidermidis); orange (P. acnes)

The above discussion regarding the scope of natural therapeutics in the form of plant extracts and various isolated secondary metabolites spells out the worth of plant-derived treatment options against acne vulgaris. These findings were proposed $C$. aurantifolia fruit juice broad relevance against acne vulgaris causing bacteria. The antiacne activity of this juice was correlated with antibacterial phytomolecules containing in the $C$. aurantifolia juice. In addition, the increasing viscosity of the formula 3 showed that the use of carbopol plays a role in the replacement of active agent that improving its bacterial inhibition.

\section{CONCLUSION}

It can be concluded that the fruit juice of $C$. aurantifolia gel formulations prepared with the concentration of $1 \%$ carbopol as gelling agents, confirm the stable physical characteristics of the base gel. In this study, the formula 3 with a concentration of $75 \%$ fruit juice presented the excellent anti-acne topical against $P$. acne and $S$. epidermidis.

\section{AUTHORS CONTRIBUTIONS}

All the author have contributed equally.

\section{CONFLICT OF INTERESTS}

\section{Declared none}

\section{REFERENCES}

1. Lynn DD, Umari T, Dunnick CA, Dellavalle RP. The epidemiology of acne vulgaris in late adolescence. Adolesc Health Med Ther 2016;7:13-25.

2. Rea JN, Newhouse ML, Halil T. Skin disease in Lambeth. A community study of prevalence and use of medical care. Br J Prev Soc Med 1976;30:107-14.

3. Wolkenstein P, Grob JJ, Bastuji-Garin S, Ruszczynski S, Roujeau JC, Revuz J. French people and skin diseases: results of a survey using a representative sample. Arch Dermatol 2003;139:1614-9.

4. Johnson MT, Roberts J. Skin conditions and the related need for medical care among persons 1-74 y. United States 19711974. Vital Health Stat 1978;11:1-72.

5. Sudharmono A. Laser Skin Resurfacing. Seminar Perspective of Laser Dermatology. Surabaya; 2008.

6. Peck GL, Olsen TG, Yoder FW, Strauss JS, Downing DT, Pandya $\mathrm{M}$, et al. Prolonged remissions of cystic and conglobate acne with 13-cis-retinoic acid. N Engl J Med 1979;300:329-33.
7. Gollnick HP, Zouboulis CC, Akamatsu H, Kurokawa I, Schulte A. Pathogenesis and pathogenesis-related treatment of acne.J Dermatol 1991;18:489-99.

8. Leyden JJ. New understanding of the pathogenesis of acne. J Am Acad Dermatol 1995;32:515-25.

9. Plewig G, Kligman AM. Acne and Rosacea. 3rd ed. SpringerVerlag, New York; 2000.

10. Cunliffe WJ, Gollnick HP. Acne: Diagnosis and management. $1^{\text {st }}$ ed. Martin Dunitz Ltd. London; 2001.

11. Kumar GS, Jayaveera KN, Ashok KCK, Umachigi PS, Vrushabendra VSM, Kishore KDV. Antimicrobial effects of Indian medicinal plants against acne-inducing bacteria. Trop J Pharm Res 2007;6:717-23.

12. Reiger M. Harry's cosmeticology. $8^{\text {th }}$ ed. Vol. 1. Chemical Publishing Co. Inc, Boston; 2009.

13. Ebling FJG. Acne vulgaris. Textbook of dermatology. $6^{\text {th }}$ ed. Blackwell Scientific, Oxford; 1998;3:552-4.

14. Farhat D, Shubbangi W, Mamta J, Gauri P. Development of herbal anti-acne gel and its evaluation against acne-causing bacteria propionibacterium acne and Staphylococcus epidermidis. Int. J Res Ayurvedha Pharm 2013;4:781-6.

15. Cunliffe WJ, Dodman B, Ead R. Benzoyl peroxide in acne. Practitioner 1978;220:479-82.

16. Fulton JE Jr, Farzad Bakshandeh A, Bradley S. Studies on the mechanism of action to topical benzoyl peroxide and Vitamin A acid in acne vulgaris. J Cutan Pathol 1974;1:191-200.

17. Bojor RA, Cunliffe WJ, Holland KT. The short-term treatment of acne vulgaris with benzoyl peroxide: effects on the surface and follicular cutaneous microflora. Br J Dermatol 1995;132:204-8.

18. Eady EA, Cove JH, Joanes DN, Cunliffe WJ. Topical antibiotics for the treatment of acne vulgaris: a critical evaluation of the literature on their clinical benefit and comparative efficacy. J Dermatol Treat 1990;1:215-26.

19. Mernadier J, Alirezai M. Systemic antibiotics for acne. Dermatology 1998;196:135-9.

20. Margolis DJ, Bowe WP, Hoffstad 0, Berlin JA. Antibiotics treatment of acne may be associated with upper respiratory tract infection. Arch Dermatol 2005; 141:1132-6.

21. Sinclair WB. Some soluble and insoluble constituents of citrus fruits. In: Sinclair WB. editor. The biochemistry and physiology of the lemon and other citrus fruits. California: the University of California, Division of Agriculture and Natural Resources; 1984. p. 79-82.

22. Babar A, Bhandari RD, Plakogiannis PM. In vitro release studies of chlorpheniramine maleate from topical bases using cellulose membrane and hairless mouse skin. Drug Dev Ind Pharm 1991;17:1027-40.

23. Velissaratou AS, Papaioannou G. In vitro release of chlorpheniramine maleate from ointment bases. Int J Pharm 1989;52:83-6.

24. Patel J, Patel B, Banwait H, Parmar K, Patel M. Formulation and evaluation of topical aceclofenac gel using a different gelling agent. Int J Drug Dev Res 2011;3:156-64.

25. Farnsworth NR. Biological and phytochemical screening of plant. J Pharm Sci 1966;55:243-69.

26. Djajadisastra J, Mun' im A, Dessy NP. Formulasi gel topical dari ekstrak nerii folium dalam sediaan anti jerawat. J Farmasi Indonesia 2009;4:210-6.

27. Sudjono TA, Honniasih M, Pratimasari YR. Pengaruh konsentrasi gelling agent carbomer 934 dan HPMC pada formulasi gel lender bekicot (Achatina Fulica) terhadap kecepatan penyembuhan luka bakar pada punggung kelinci. Pharmacon 2012;13. 
28. Kusuma SAF, Soraya RM, Indah F, Resmi M. Study on the antibacterial activity of fruit extracts of Klutuk Banana (Musa balbisianacolla) against Shigella dysenteriae ATCC 13313. Asian J Pharm Clin Res 2017;10:220-3.

29. Zlotogorski A. Distribution of skin surface $\mathrm{pH}$ on the forehead and cheek of adults. Arch Dermatol Res 1987;279:398-401.

30. Raphael KL, Murphy RA, Shlipak MG. Health ABC Study. Bicarbonate concentration, acid-base status, and mortality in the health, aging, and body composition study. Clin J Am Soc Nephrol 2016;pii:CJN.06200615.

31. Lambers H, Piessens S, Bloem A, Pronk H, Finkel P. Natural skin surface $\mathrm{pH}$ is on average below 5 , which is beneficial for its resident flora. Int J Cosmet Sci 2006;28:359-70.

32. Prakash C, Bhargava P, Tiwari S, Majumdar B, Bhargava RK. Skin surface $\mathrm{pH}$ in acne vulgaris: insights from an observational study and review of the literature. J Clin Aesthet Dermatol 2017;10:33-9.

33. Seidenari S, Francomano M, Mantovani L. Baseline biophysical parameters in subjects with sensitive skin. Contact Dermatitis 1998;38:311-5.

34. Panther DJ, Jacob SE. The importance of acidification in atopic eczema: an underexplored avenue for treatment. J Clin Med 2015;4:970-8.

35. Berg RW, Milligan MC, Sarbaugh FC. Association of skin wetness and $\mathrm{pH}$ with diaper dermatitis. Ped Dermatol 1994;11:18-20.

36. Korting $\mathrm{HC}$, Braun-Falco $\mathrm{O}$. The effect of detergents on skin $\mathrm{pH}$ and its consequences. Clin Dermatol 1996;14:23-7.

37. Tagami H. Location-related differences in structure and function of the stratum corneum with special emphasis on those of the facial skin. Int J Cosmet Sci 2008;30:413-4.
38. Korting HC, Hubner K, Greiner K, Hamm G, Braun-Falco O. Differences in the skin surface $\mathrm{pH}$ and bacterial microflora due to the longterm application of synthetic detergent preparations of $\mathrm{pH} 5.5$ and $\mathrm{pH}$ 7.0. Results of a crossover trial in healthy volunteers. Acta Derm Venereol 1990;70:429-31.

39. Kum H, Roh KB, Shin S, Jung K, Park D, Jung E. Evaluation of anti-acne properties of phloretin in vitro and in vivo. Int J Cosmet Sci 2016;38:85-91.

40. Charde YM, Sharma PH, Choudhary NG, Avari JG. Development and evaluation of herbal formulation for the treatment of acne. Int J Pharm Sci Res 2014;5:2250-60.

41. Blumenthal M, Busse WR, Godlberg A. The complete german commission E monographs; a therapeutic guide to herbal medicines. Am Botanical Council Texas; 1998.

42. Rafieian-Kopaei M. Medicinal plants and the human needs. J Herb Med Pharmacol 2013;1:1-2.

43. Sharma S, Pawar S, Jain UK. Development and evaluation of topical gel of curcumin from a different combination of polymers formulation and evaluation of herbal gel. Int J Pharm Pharm Sci 2012:4:452-6.

44. Blanco Fuente, Anguiano Igea, Otero Espinar Francisco, Mendez, Jos A. In vitro bioadhesion of carbopol hydrogels. Int J Pharm 1996;142:169-74.

45. Mohammad IT, Nair RH, Susan C, Chrisita A. Rheological characterization of topical carbomer gels neutralized to different pH. Pharm Res 2004;21:1192-9.

46. Panigrahi L, Jhon T, Shariff A, Shobanirani RS. Formulation and evaluation of lincomycin $\mathrm{HCl}$ gels. Indian $\mathrm{J}$ Pharm Sci 1997; 59:330-2.

47. Kaur D, Raina A, Singh N. Formulation and evaluation of Carbopol 940 based Glibenclamide transdermal gel. Int J Pharm Pharm Sci 2014;6:434-40. 